\title{
O Que é a Informática
}

J. W. BAUTISTA VIDAL

Secretário de Ciências e Tecnologia do Govêrno do Estado da Bahia

A informática constitui o fundamento da moderna administração cientifica.

Introduzir na administração a metodologia científica tem sido um dos objetivos de inúmeros países que visam à racionalização das suas estruturas e procedimentos, especialmente daqueles onde a máquina do poder público adquiriu a rigidez e a inércia que a torna incompativel com seus anselos de desenvolvimento. Uma das características mais preponderantes dos países subdesenvolvidos é a ineficiência da sua máquina administrativa, esclerosada e fluída, inconsistente e cara. Onde menos se deveria admitir desperdício, conseqüentemente exigindo uma rigorosa aplicação dos parcos recursos existentes, é precisamente onde, com mais fartura, ocorre o desPerdício. Desperdício devido à dupliCação de ação, à falta de coordenação, à carência de pessoal competente, à inércia, morosidade, ao uso de técnicas antiquadas e obsoletas, ao excesso de bưrocracia.

A chave do sucesso e do progresso de um país não reside sòmente na sua estrutura econômica, na sua estrutura social ou mesmo na sua estrutura Política mas, principalmente, na sua capacidade administrativa. Esta não depende apenas da qualidade pessoal dos dirigentes e dos funcionários administrativos, mas da eficácia de um sistema de informações e de contrôle, bem como dos mecanismos de decisão; isto explica o desnivel entre as economias avançadas $e$ as atrasadas.

Quando os problemas administrativos de um pais decorrem de um objetivo processo de desenvolvimento, a situação torna-se mais crítica e a falta de um sistema administrativo moderno pode conduzir a resultados opostos aos esperados.

A tarefa de adequar uma máquina administrativa obsoleta aos objetivos do desenvolvimento não é simples e exige grandes e persistentes esforços, como base em sérios estudos sujeitos a uma metodologia precisa. Esta metodologia deve conduzir a uma redução drástica de todo desperdício de material, de tempo, de espaço e de energia. O resultado geral será a prática de procedimentos simples porém rápidos, seguros e menos custosos. Usualmente tem-se utilizado a racionalização do procedimento administrativo particularmente no setor público, aplicando conceitos de administraçăo científica de

Transcrito da revista Aratu de malo de 1970, Ano III, n.o 33. 
maneira fragmentária e improvisada, o que pode agravar ainda mais a situação.

A implementação de sistemas de informação flexíveis e atualizados constitui o ponto de partida imprescindível para reorganizar, real e efetivamente, as estruturas da administração pública e privada. Uma vez coberta esta primeira etapa com a acumulação de dados, o que é possível graças aos modernos sistemas de computação automática, convém prever 0 uso de metodologias mais elaboradas, como a estatística e a pesquisa operacional. Nesta altura do processo, os funcionários responsáveis, dirigentes e executivos, disporão dos instrumentos necessários para otimizar as decisões, possibilitando um aumento sensível da eficiência e um crescimento dinâmico nas áreas de planejamento, pesquisa, programação, gerência e contrôle, atualmente impregnados de rotinas anquilosadas.

Entre os problemas maiores na instalação de um sistema de informação para a Coordenação Governamental destaca-se o agudo "deficit" de pessoal especializado, particularmente o de alto nível (analista e engenheiros de sistemas). Na Bahia, o trabalho da instalação de um Centro de Informática começou em setembro de 1969, exatamente pela seleção de 20 técnicos, de nível superior, que estão sendo submetidos a um treinamento intensivo na Secretaria da Ciência e Tecnologia.
Entre os problemas maiores na instalação de um tal sistema destacaramse a compatibilização dos programas, a coordenação das tarefas de computação, para evitar-se superposição $e$ duplicação de esforços, e a adoção de uma política definida, que exige a realização de estudos e a busca de soluções coerentes em todo o âmbito da administração pública. Êste conjunto de problemas implica na existência de um órgão governamental único capaz de orientar o processo de aplicação da informática e, em particular, da computação, pelos caminhos certos, $\mathrm{com}$ visão do conjunto. Isto é o que está sendo implantado, como experiência única no País, pelo Govêrno do EStado da Bahia, com a criação do Centro de Informática.

Alguns países da América Latina, tais como o Chile, a Argentina e 0 México, possuem experiências nacionais de sistemas integrados de informática. No caso do Brasil, dadas as suas dimensöes continentais e a diversidade de regiões geoeconômicas năo seria viável, a curto prazo, a instalação de um sistema nacional de informática, sendo exatamente recomendável, entretanto, o estabelecimento do sistemas estaduais que, no futuro, venham a se integrar em um sistema nacional. A própria estrutura política do País assim o recomenda. Além do Estado da Bahia, os Estados de Săo Paulo, Rio e Guanabara estão estudando a instalação de seus sistemas informativos. 